\title{
Don Hellison's Life and Legacy: Introduction to the Special Issue
}

\author{
Paul M. Wright \\ David Walsh \\ Northern Illinois University San Francisco State University
}

\begin{abstract}
Don Hellison (1938-2018) was a leader and trailblazer in sport and physical education pedagogy. Early in his career, he was an advocate for humanistic physical education. His engaged approach to scholarship culminated in the development of the Teaching Personal and Social Responsibility (TPSR) model, which is now recognized as a best practice for promoting social and emotional learning in physical education. The TPSR model has also been widely applied in the field of sport-based youth development. This is the introduction to the special issue devoted to Don's life and legacy. It provides opening comments from the guest editors and a brief overview of the articles in the special issue.
\end{abstract}

Keywords: humanistic physical education, personal and social responsibility, social and emotional learning, sport-based youth development, tribute

This special issue of Journal of Teaching in Physical Education celebrates the life and legacy of Don Hellison (1938-2018). Through a career spanning more than four decades, Don established himself as a thoughtful leader and trailblazer in sport and physical education pedagogy. He was an early champion of humanistic physical education (Hellison, 1973, 1978), and this work culminated in the development of his teaching personal and social responsibility (TPSR; Hellison, 1995, 2003, 2011) model. In a retrospective viewpoint article written for Journal of Physical Education, Recreation and Dance, Don discussed three contributions to which he was the most committed across his career (Hellison, 2008, p. 9). These were as follows:

- An as-seamless-as-possible blend of practice and theory (or theory research) in which practice informs theory just as much as the other way around.

- A focus on underserved youths with the lofty goal of trying to level the playing field a bit.

- A holistic educational perspective for kids' physical activitybased programs that capitalizes on the uniqueness of physical activity embedding social, emotional, and cognitive life skills and values in the physical activity content.

Regarding the questions that drove his scholarship, in the same article, he described them as "what is worth doing, what's possible, and is it working" (p. 8)?

These commitments and driving questions helped Don fulfill his sense of purpose and ultimately established him as one of the most influential scholars in physical education and sport pedagogy. Although his approach placed him on the margins of his field for much of his early career (Hellison \& Martinek, 2009), by the time of his passing, Don had influenced research, practice, curriculum, and teacher/coach education around the globe. Perhaps, as Wright (2009) observed, as the margins of what is valued in this field continue to shift, we can better appreciate Don's innovation and contribution. Consider, for example, how the current surge of interest

Wright is with Northern Illinois University, Dekalb, IL, USA. Walsh is with San Francisco State University, San Francisco, CA, USA. Wright (pwright@niu.edu) is corresponding author. in social and emotional learning in physical education invokes so many of the ideas and practices Don was promoting from the margins decades ago (Gordon, Jacobs, \& Wright, 2016; Jacobs \& Wright, 2014; Wright, Gordon, \& Gray, in press).

Don always made it clear that his scholarship could not be separated from his experiences, beliefs, or values (Hellison, 2008). Because of who Don was as a person and the relationships that he built, he earned the respect and admiration of countless youths, teachers, coaches, and scholars working in physical education and other physical activity settings. He did not just influence a body of literature and an academic subdiscipline, he influenced people. We (Paul and Dave) are two people whose lives, personal and professional, were greatly influenced by Don (Walsh \& Wright, 2016). We were his students, protégés, friends, and collaborators. Like many others we know, it is impossible to say what course our lives would have taken if it had not been for Don's influence. For these reasons and with a sense of gratitude and love, we have taken on the role of guest editors for this special issue.

While this special issue is a tribute to Don, our aim is not just to reminisce, share stories, and summarize Don's accomplishments. We have worked with the various contributors to take a serious (but not detached) look at Don's life and legacy. In each article, the authors have focused on a particular aspect. They have all used a specific lens and analytic approach to understand a unique facet of Don's story. We believe each of these articles is a valuable resource in and of itself, offering insights from individuals who knew Don well and care deeply about the work he began. However, to avoid redundancy, we have encouraged the authors to set their focus with an understanding of its place within the issue. Therefore, the authors cross-reference one another extensively, and we believe that viewed as an integrated whole, this special issue is a comprehensive and coordinated treatment of Don's life and legacy. The following section provides a brief overview of the articles in this special issue.

\section{Overview}

It is difficult, in the case of Don Hellison, to separate the man from his work. However, our first article, written by Jenn Jacobs and 
Tom Templin, addresses a gap in the literature by providing a detailed biographical sketch. The article entitled "The Man Behind the Teaching Personal and Social Responsibility Model: A Life History of Don Hellison" provides a biography of Don focusing on various phases of his life from childhood to his education, military service, academic career, and retirement. These experiences shaped who he was as a person and his life's work. To a great extent, this article uses Don's own words and stories gleaned from his reflective writing and several oral history interviews. This article contextualizes the phases and key milestones of Don's life and academic career against the backdrop of what was occurring contemporaneously in society and education.

The second article, entitled "What's Worth Doing?: A Qualitative Historical Analysis of the TPSR Model," is authored by Kevin Richards and Victoria Ivy. This article does focus more on Don's work. Framed as a qualitative historiography, this article uses content analysis to trace the evolution of Don's teaching approach through several iterations of what he ultimately called the TPSR model. A deep and thoughtful review of Don's writing across the years provides the reader with a sense of Don's process in developing the TPSR model and makes it clear that he always viewed it as a work in progress or a "theory in action" rather than something dogmatic and set in stone.

The third article is written by Paul Wright, Karissa Fuerniss, and Nick Cutforth. In this article, entitled "Don Hellison's Scholarship Reconsidered," the authors explore Don's views on scholarship, his alternative approach, and his advocacy for broader and more inclusive definitions of scholarship in higher education. The authors describe and interpret Don's scholarship and the work it spawned through the lens of Boyer's (1990) framework for scholarship reconsidered. Consistent with Boyer's framework, Don's approach to scholarship struck a balance between discovery, application, integration, and teaching. The authors illuminate how these various aspects of scholarship were evident in Don's original work and remain strong in the ever-expanding body of TPSR scholarship.

The fourth article examines Don's impact and position within the broader field of physical education pedagogy. This article, written by Hans van der Mars and entitled "Principled, Modest, and Giving . . . Don Hellison's Impact Through the Eyes of His Peers," summarizes and interprets perceptions of Don from other respected and highly accomplished figures in the field. Hans elicited stories, observations, and insights from Chuck Corbin, Sarah Doolittle, Doune Macdonald, Thom McKenzie, Mike Metzler, Missy Parker, Judy Rink, and Tom Templin. Understanding how Don was perceived by this cross section of his peers provides a sense of the mark that he made, both personally and professionally.

Tom Martinek and Michael Hemphill authored the fifth article, which is entitled "The Evolution of Hellison's Teaching Personal and Social Responsibility Model in Out-of-School Contexts." Unlike the preceding article which speaks largely to Don's impact on physical education, this article examines his work and contributions in out-of-school settings in the area of positive youth development. Much of Don's fieldwork was done in YMCAs, Boys and Girls Clubs, as well as before and after school programs in underserved communities. This article provides a rich description of Don's community-engaged approach and commitment to working directly with underserved youth. This article also demonstrates the versatility of TPSR, given that different settings (e.g., inschool physical education, after-school programs) present different challenges and opportunities.

The next article, "Expanding the Boundaries of TPSR and Empowering Others to Make Their Own Contributions," is written by Barrie Gordon and Sylvie Beaudoin. In this article, the authors describe the spread of TPSR around the globe, highlighting individuals and sites that have been critical to the model's dissemination and growth. They provide examples of innovation and adaptations to TPSR by creative folks who were making the model their own while trying to meet the needs of their students (as Don often advised). This review of TPSR's dissemination and adaptation prompts a discussion of implementation fidelity and the challenge of striking a balance between flexibility and staying true to the essential values and practices underpinning Don's work.

Finally, Robin Dunn and Sarah Doolittle have written "Professional Development for Teaching Personal and Social Responsibility: Past, Present, and Future." In this article, the authors recount the various ways that Don shared his ideas and "taught" others about TPSR. From extended apprenticeships with a small number of individuals to the formation of a community of practice called the TPSR Alliance (Walsh \& Wright, 2016), training in TPSR has taken many forms over the years. The authors discuss opportunities, struggles, and emerging best practices related to promoting and sharing this work in preservice teacher education, in-service professional development, and coach training.

As noted at the start of the introduction, this special issue is intended to celebrate Don's life and his life's work. While it certainly reflects deep affection and admiration for Don, we hope it also serves as an important record of the man, his work, and his influence. We hope the new information, fresh insights, and informative analyses contained in these pages do justice to Don by documenting how deep, widespread, and layered his impact was. In this way, we hope this special issue prompts reflection and that Don's example of a life well lived inspires readers now and in the future.

\section{Acknowledgments}

The authors would first like to thank Drs. Mark Byra and Bryan McCullick, coeditors of Journal of Teaching in Physical Education, for their openness and support of this special issue as well as their coaching and insightful feedback through the process. They also acknowledge Sharon Van Oteghen (posthumously) and Nikos Georgiadis, whose thorough and timely projects documenting Don's life story and process of curriculum development provided important information for several of the articles in this special issue. Finally, the authors recognize that they and the contributing authors represent just a small portion of the TPSR community. To the countless youths, practitioners, and academics whose collaboration with Don and contributions to TPSR may not be featured in this special issue, you have our gratitude.

\section{References}

Boyer, E.L. (1990). Scholarship reconsidered: Priorities of the professoriate. Lawrenceville, NJ: Princeton University Press.

Gordon, B., Jacobs, J.M., \& Wright, P.M. (2016). Social and emotional learning through a teaching personal and social responsibility based after-school program for disengaged middle-school boys. Journal of Teaching in Physical Education, 35(4), 358-369. doi:10.1123/jtpe. 2016-0106

Hellison, D. (1973). Humanistic physical education. Englewood Cliffs, NJ: Prentice-Hall.

Hellison, D. (1978). Beyond balls and bats: Alienated (and other) youth in the gym. Washington, DC: American Association for Health, Physical Education, and Recreation. 
Hellison, D. (1995). Teaching responsibility through physical activity. Champaign, IL: Human Kinetics.

Hellison, D. (2003). Teaching responsibility through physical activity (2nd ed.). Champaign, IL: Human Kinetics.

Hellison, D. (2008). This I believe about our field. Journal of Physical Education, Recreation \& Dance, 79(7), 6-9. doi:10.1080/07303084. 2008.10598205

Hellison, D. (2011). Teaching responsibility through physical activity (3rd ed.). Champaign, IL: Human Kinetics.

Hellison, D., \& Martinek, T. (2009). Living in the margins of our field. In L. Housner, M. Metzler, P. Schempp, \& T. Templin (Eds.), Historic traditions and future directions of research on teaching and teacher education in physical education (pp. 267-270). Morgantown, WV: Fitness Information Technology.

Jacobs, J., \& Wright, P. (2014). Social and emotional learning policies and physical education: Column Editor: K. Andrew
R. Richards. Strategies, 27(6), 42-44. doi:10.1080/08924562. 2014.960292

Walsh, D., \& Wright, P.M. (2016). The TPSR alliance: A community of practice for teaching, research, and service. Journal of Physical Education, Recreation \& Dance, 87(5), 35-38. doi:10.1080/07303084.2016. 1157394

Wright, P.M. (2009). Research on the teaching personal and social responsibility model: Is it really in the margins? In L. Housner, M. Metzler, P. Schempp, \& T. Templin (Eds.), Historic traditions and future directions of research on teaching and teacher education in physical education (pp. 289-296). Morgantown, WV: Fitness Information Technology.

Wright, P.M., Gordon, B., \& Gray, S. (in press). Social and emotional learning in the physical education curriculum. In W.H. Schubert \& M. Fang (Eds.), Oxford encyclopedia of curriculum studies. Oxford, United Kingdom: Oxford University Press. 